\title{
Respiratory Physiology of the Lake Magadi Tilapia (Oreochromis alcalicus grahami), a Fish Adapted to a Hot, Alkaline, and Frequently Hypoxic Environment
}

\author{
Annie Narahara ${ }^{1, *}$ \\ Harold L. Bergman ${ }^{1}$ \\ Pierre Laurent $^{2}$ \\ J. N. Maina ${ }^{3}$ \\ Patrick J. Walsh ${ }^{4}$ \\ Chris M. Wood ${ }^{5}$
}

${ }^{1}$ Department of Zoology and Physiology, University of Wyoming, Laramie, Wyoming 82071; ${ }^{2}$ Laboratoire de Morphologie Fonctionnelle et Ultrastructurale des Adaptations, Centre d'Ecologie et de Physiologie Energétique, CNRS, BP20CR, F-67037 Strasbourg cedex, France; ${ }^{3}$ Department of Veterinary Anatomy, University of Nairobi, Chiromo Campus, P.O. Box 30197, Nairobi, Kenya; ${ }^{4}$ Division of Marine Biology and Fisheries, Rosenstiel School of Marine and Atmospheric Science, University of Miami, Miami, Florida 33149; ${ }^{5}$ Department of Biology, McMaster University, Hamilton, Ontario L8S 4K1, Canada

Accepted 12/5/95

\begin{abstract}
The tilapia Oreochromis alcalicus grahami is a unique ureotelic teleost, the only fish that lives in the alkaline hotsprings of Lake Magadi, Kenya. Physical conditions and fish behavior were monitored in the Fish Springs Lagoon area, a site where the tilapia were particularly abundant. Water $\mathrm{PO}_{2}$ and temperature fluctuated more or less in parallel in a diurnal cycle from less than 20 Torr and less than $25^{\circ} \mathrm{C}$ at night to greater than 400 Torr and $38^{\circ} \mathrm{C}$ during the day, whereas pH remained constant at approximately 9. 8. Field laboratory tests demonstrated that routine $\dot{M}_{2}$ (under normoxia) increased greatly from $27^{\circ} \mathrm{C}$ to $36^{\circ} \mathrm{C}\left(Q_{10}\right.$ $=6.2)$ but then stabilized at a very high level $\left(\sim 34.5 \mu \mathrm{mol} \mathrm{g}^{-1} \mathrm{~b}^{-1}\right)$ up to the lethal temperature $\left(\sim 42.5^{\circ} \mathrm{C}\right)$, a pattern that was adaptive to the natural diurnal regime. The $\mathrm{PO}_{2}$ threshold for survival during acute exposure ( $\left.\leq 1 \mathrm{~b}\right)$ was approximately 16 Torr. $\dot{M O}_{2}$ from water was well maintained down to a $\mathrm{PO}_{2}$ of 60 Torr, below which it declined. Under such hypoxic conditions, the fish performed supplementary surface breathing when allowed access to air. Both the better oxygenated surface layer and air bubbles were inspired, resulting in significant uptake of $\mathrm{O}_{2}$. The $\mathrm{PO}_{2}$ threshold for surface breathing was 1.8 -fold higher at $37.5^{\circ} \mathrm{C}$ than
\end{abstract}

\footnotetext{
* To whom correspondence should be addressed.
}

Physiological Zoology 69(5):1114-1136. 1996. (C) 1996 by The University of Chicago. All rights reserved. 0031-935X/96/6905-9534\$02.00 
at $31^{\circ} \mathrm{C}$. Surface breathing and voluntary entry of fish into air were observed in the field. The blood $\mathrm{O}_{2}$ dissociation curve at $30^{\circ}-32^{\circ} \mathrm{C}$ was byperbolic, with a high affinity $\left(P_{50}=6\right.$ Torr $)$, low cooperativity (Hill coefficient $\left.=1.18\right)$, and no Bobr effect over the extracellular pH range 8.2-8.6.

\section{Introduction}

The tilapia Oreochromis alcalicus grabami is the only fish species known to exist in the highly alkaline pools fed by geothermal springs at Lake Magadi in the Rift Valley of Kenya (Coe 1966). This fish thrives in a hostile environment (water of pH 9.6-10.4, osmolality $=525 \mathrm{mOsmol} \mathrm{kg}{ }^{-1}, \mathrm{CCO}_{2}=180$ mmol L ${ }^{-1}$, temperature $\leq 42^{\circ} \mathrm{C}$ ), with intense predation by birds. Coe (1966) and Trewevas (1983) have described the physical properties of the lake and much of the basic biology of $O$. alcalicus grabami, while Reite et al. (1974) have documented its resistance to high $\mathrm{pH}$ and high temperature. Earlier studies have investigated various aspects of its ionoregulatory physiology (Leatherland et al. 1974; Johansen et al. 1975; Maetz and De Renzis 1978; Maloiy et al. 1978; Skadhauge et al. 1980; Eddy et al. 1981; Eddy and Maloiy 1984). More recent studies have concentrated on its unique ability to excrete all nitrogenous waste as urea rather than ammonia through expression of a full complement of ornithine-urea cycle enzymes in the liver and the possible relationship of this trait with acid-base balance (Randall et al. 1989; Wood et al. 1989, 1994; Wright et al. 1990; Walsh et al. 1993; Laurent et al. 1995).

Rather less is known about the respiratory physiology of $O$. alcalicus grahami. Blood pH's, both extracellular and intracellular, are high relative to the predictions of standard $\mathrm{pH}$ versus temperature relations in fish (Cameron 1984), reflecting low $\mathrm{PCO}_{2}$ and high $\mathrm{HCO}_{3}^{-}$levels (Johansen et al. 1975; Johnston et al. 1983; Wood et al. 1989, 1994). The only study on $\mathrm{O}_{2}$ transport in this species used a dialyzed hemolysate of whole blood rather than intact red cells (Lykkeboe et al. 1975). At $35^{\circ} \mathrm{C}, \mathrm{O}_{2}$ affinity of this stripped hemoglobin was high $\left(\mathrm{P}_{50}=4\right.$ Torr $)$ and there was no Bohr effect over what is the probable physiological $\mathrm{pH}$ range (7.5-8.5). Despite the high environmental temperature, the hemoglobin does not exhibit unusual thermostability (Franklin et al. 1994). Maina (1990) reported that respiratory surface area of the gills was unusually high and diffusion distance low, presumably adaptations to hypoxia and/or high metabolic rates.

The present study investigates several aspects of the respiratory physiology of this unique species. Our first objective was to characterize the temperature and $\mathrm{O}_{2}$ conditions faced by $\mathrm{O}$. alcalicus grabami in its natural environment and to relate this to the fish's behavior. The Fish Springs Lagoon area (see 
Coe 1966), employed as the collection site in this and virtually all previous studies on the Magadi tilapia, was chosen as the study site. We suspected that large diurnal fluctuations in dissolved $\mathrm{O}_{2}$ might occur because the lagoon supports an abundant growth of cyanobacteria (the principal food source for the fish). Cyanobacteria perform photosynthesis and respiration during the day but only the latter at night. The second objective was to determine the effect of environmental temperature and $\mathrm{PO}_{2}$ on the oxygen consumption rate $\left(\dot{M}_{2}\right)$ of these fish and to assess their resistance to hypoxia. A third, and related, objective was to investigate the possible respiratory significance of apparent air and/or surface breathing that we had observed in fish in the lagoon during our first several days at Lake Magadi and the effects of water $\mathrm{PO}_{2}$ and temperature on this behavior. The final objective was to determine the blood $\mathrm{O}_{2}$ transport characteristics ( $\mathrm{P}_{50}, \mathrm{pH}$ sensitivity) of intact, freshly collected whole blood of $O$. alcalicus grabami for comparison with the earlier observations of Lykkeboe et al. (1975) on stripped hemoglobin. All experiments were performed in a makeshift outdoor laboratory on fish freshly collected from the wild.

\section{Material and Methods}

\section{Experimental Animals}

Small adult Oreochromis alcalicus grabami (1-4 g) used in most experiments were collected with a seine in January and February, 1992, from the Fish Springs Lagoon site on Lake Magadi, Kenya, described by Coe (1966). Much larger adult fish (10-40 g) used as blood donors for the $\mathrm{O}_{2}$ dissociation curve determinations were seined from a cement holding tank supplied with a continuous flow of lagoon water. An incidental population of $O$. alcalicus grabami lives in the tank, the initial stock having been pumped in with the water. Because this population is protected from intense avian predation by a chain-link fence and by the water depth in the tank, average fish size is much larger than in the lagoon population. Fish were immediately transported to an outdoor laboratory set up on the porch of the chemistry building of the Magadi Soda Company and transferred to fresh aerated lagoon water in 20-L buckets kept in the shade. Temperature ranged from $30^{\circ}$ to $36^{\circ} \mathrm{C}$ diurnally, similar to that at the fish collection site (see Results). These fish are extremely territorial and aggressive; we found higher survival rates when fish density was less than 10 fish per $20 \mathrm{~L}$ and when the bucket was covered. Fish were deprived of food after capture and used within $24 \mathrm{~h}$ for experiments; survivors were returned to the wild. 


\section{Diurnal Dissolved $\mathrm{O}_{2}$ Concentrations}

Figure 1 is a map of the Fish Springs Lagoon field site, with individual data collection points depicted for $\mathrm{PO}_{2}, \mathrm{pH}$, and temperature measurements. The site has been modified by a retaining wall and an overflow dam of many years' standing (Coe 1966); the barrier serves to collect water for the carbonate trona processing operations of Magadi Soda Company. Some of this water is pumped elsewhere, and overflow from the pump house collects in a large pond. Temperature, $\mathrm{pH}$, and $\mathrm{PO}_{2}$ of the Fish Springs Lagoon sites (typical depth $=1 \mathrm{~m}$ ) were determined by a mercury thermometer and a YSI Model $54 \mathrm{pH}$ and $\mathrm{O}_{2}$ meter; the standard polarographic membrane $\mathrm{O}_{2}$ probe was calibrated with air, with appropriate corrections for ambient temperature and the 700-m elevation of the site. The dissolved $\mathrm{O}_{2}$ (DO), $\mathrm{pH}$, and temperature readings were collected on most days in January, and systematic measurements over discrete intervals and depths were made January 22 and 29-30. Measurements were made at 14 sites at the surface $(5-10 \mathrm{~cm}$ below surface) and bottom (2-3 cm from bottom). DO values were converted to $\mathrm{PO}_{2}$ with appropriate salinity-corrected solubility coefficients from Boutilier et al. (1984).

\section{Effect of Temperature on $\dot{M}_{2}$}

Closed-system respirometry in 530-mL Tusker chambers (amber Tusker beer bottles fitted with aeration tubes and ports for drawing 1-mL syringe samples anaerobically) kept in the shade was used to determine the effect of temperature on routine $\dot{\mathrm{M}}_{2}$ of $\mathrm{O}$. alcalicus grabami. We use the term "routine" as defined by Fry (1957) to refer to $\dot{M O}_{2}$ in unfed fish with spontaneous rather than directed movements. Small adult fish (1-4 g) were loaded into Tusker chambers filled with continuously aerated lagoon water at approximately $27^{\circ} \mathrm{C}$ and then allowed to settle for $30 \mathrm{~min}$. Aeration was then stopped, and the chambers were sealed, with care taken not to trap any air bubbles, thereby eliminating any attempts of the fish to obtain $\mathrm{O}_{2}$ from the air or the air-water interface. Subsequent runs were done on the same fish with fresh lagoon water at higher temperatures (up to $42^{\circ} \mathrm{C}$, water preheated by exposure to direct sunlight) as ambient temperature increased over the day in the outdoor laboratory. The decrease in water $\mathrm{PO}_{2}$ over 10-60-min intervals was monitored with a Radiometer $\mathrm{E} 5046 \mathrm{O}_{2}$ electrode attached to a pHM 71 meter thermostated to the experimental temperature. The $\mathrm{PO}_{2}$ calibration at time zero was based on the current experimental temperature, with a correction factor of 1.03 for measuring the $\mathrm{PO}_{2}$ of water when calibrating on air. A chamber containing water but no fish was included in each series to serve as a blank. 


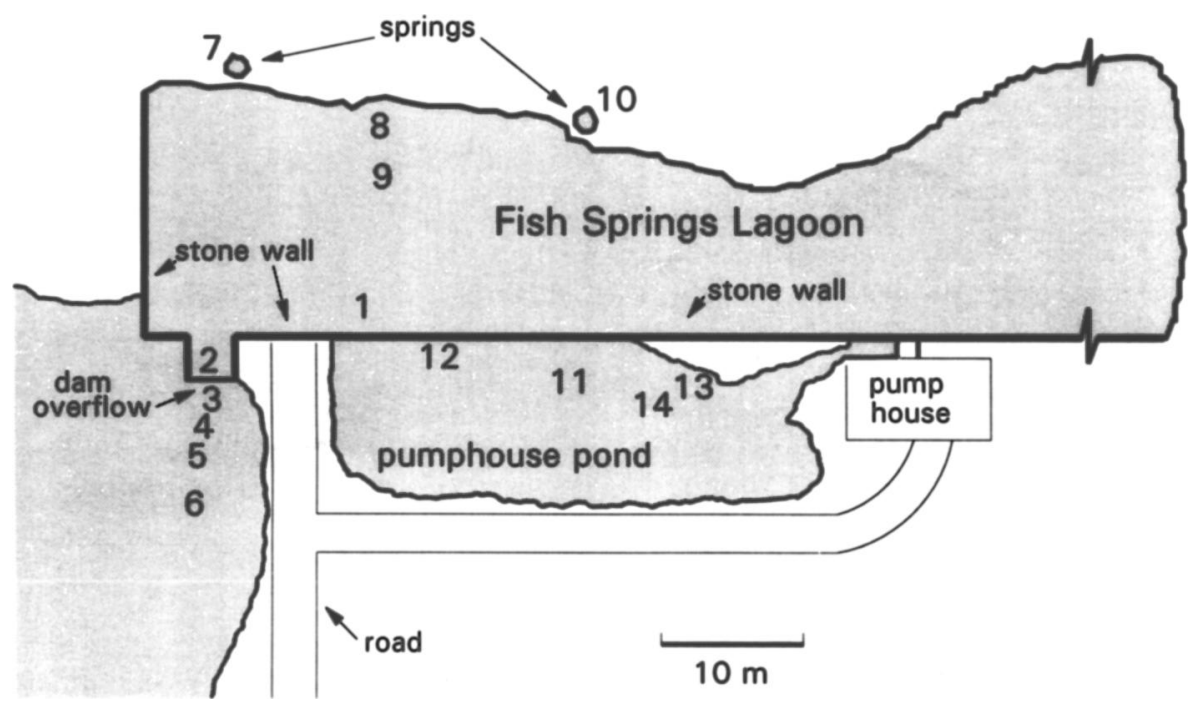

Fig. 1. A diagrammatic map of the Fish Springs Lagoon area on the edge of Lake Magadi, Kenya, indicating the 14 monitoring sites for water temperature and partial pressure of oxygen $\left(\mathrm{PO}_{2}\right)$. See Table 1 for the range of values for each site.

\section{Effect of Temperature on Threshold $\mathrm{PO}_{2}$ for Surface Breatbing}

Small adult fish (1-4 g) were placed into aerated Tusker chambers at either $31^{\circ} \mathrm{C}(N=12)$ or $37.5^{\circ} \mathrm{C}(N=11)$ and allowed to settle for $1 \mathrm{~h}$. Aeration was then stopped, and an air bubble introduced into the neck of the chamber. The fish were then observed continuously as they depleted the $\mathrm{O}_{2}$ from the water. $\mathrm{PCO}_{2}$ did not increase, because of the very high absorptive capacity of the water for $\mathrm{CO}_{2}$ at $\mathrm{pH}$ 10. As soon as the fish was observed to first breathe from the air or air-water interface, a water sample was drawn for measurement (as above) of the threshold $\mathrm{PO}_{2}$ for this behavior.

\section{Effect of Water $\mathrm{PO}_{2}$ on $\dot{\mathrm{M}} \mathrm{O}_{2}$}

Flow-through respirometry was used to measure changes in $\dot{\mathrm{MO}}_{2}$ in response to changes in $\mathrm{PO}_{2}$. Respirometers were darkened 50-mL centrifuge tubes cut off at one end and sealed with rubber stoppers; three-way valves at both ends facilitated anaerobic sampling of inflow and outflow water into $1-\mathrm{mL}$ syringes. A 20 - $\mathrm{L}$ bucket filled with aerated lagoon water at $31^{\circ}-32^{\circ} \mathrm{C}$ served as a head tank. Flow rates were adjusted by volumetric measurement to 9$11 \mathrm{~mL} \mathrm{~min}^{-1}$. Small adult fish $(2-4 \mathrm{~g} ; N=12)$ were allowed to settle for about $1.5 \mathrm{~h}$ as the respirometers were flushed with near-saturated water $\left(\mathrm{PO}_{2}\right.$ $>130$ Torr, where 1 Torr $=133.322 \mathrm{~Pa}$ ) before control $\dot{M}_{2}$ measurements 
were made in duplicate. The $\mathrm{PO}_{2}$ was then lowered to a new constant level by gassing the head tank with $\mathrm{N}_{2}$; the fish was allowed to adjust to the new $\mathrm{PO}_{2}$ for about $30 \mathrm{~min}$, and then $\dot{\mathrm{MO}}_{2}$ was measured again in duplicate. Each fish was exposed to seven or eight levels of $\mathrm{PO}_{2}$ between 135 and 25 Torr. In each case, the exposure $\mathrm{PO}_{2}$ was taken as the mean of the measured inflow and outflow $\mathrm{PO}_{2}$ values.

\section{Critical $\mathrm{PO}_{2}$ for Survival}

In the course of a separate study comparing urea excretion and $\dot{\mathrm{M}}_{2}$ (Wood et al. 1994), $\dot{M O}_{2}$ measurements were made by closed-system respirometry in 530-mL Tusker chambers on several hundred small adult fish (1-5 g) at $30^{\circ}-33^{\circ} \mathrm{C}$. Seven of these fish died because the water $\mathrm{PO}_{2}$ was accidentally permitted to fall too low. Water $\mathrm{PO}_{2}$ measurements were made within 5 min of death for these fish and recorded as the critical $\mathrm{PO}_{2}$ for survival. In addition, records were kept of unusually low $\mathrm{PO}_{2}$ 's at which fish survived and of $\mathrm{PO}_{2}$ 's associated with death of some individuals in the preceding flow-through respirometry experiments.

\section{Bebavioral Observations of Respiration}

A 20-L glass aquarium was built for behavioral observations of $O$. alcalicus grabami in aerated and nonaerated Fish Springs water, which was changed daily. The temperature was allowed to fluctuate diurnally with ambient air temperature. The sides were masked to reduce the effects of outside stimuli on behavior, and the top was left open for natural light cycles. One to three fish were held in the aquarium at any one time. We noted periods of air or surface breathing and measured the incidental water temperature and $\mathrm{PO}_{2}$. We also noted any other unusual behaviors by the fish.

\section{$\dot{M}_{\mathrm{O}_{2}}$ from Water and Air during Hypoxic Conditions}

In the laboratory, air breathing was observed only at times of low water $\mathrm{PO}_{2}$. Therefore, the objective of this series of experiments was to partition $\dot{\mathrm{M}}_{2}$ from air versus $\dot{M}_{2}$ from water during aquatic hypoxia and to compare the total $\dot{M}_{2}$ with that seen under normoxic control conditions. Flow-through respirometry was used for $\dot{\mathrm{MO}}_{2}$ from water (to maintain near-constant water $\mathrm{PO}_{2}$ ) and closed-system respirometry for $\dot{\mathrm{MO}}_{2}$ from air. Smaller, 350-mL Tusker chambers were set up on a flow-through basis $\left(9-11 \mathrm{~mL} \mathrm{~min}^{-1}\right.$ ), with water entering at the bottom and leaving by siphon close to the top. In addition to sampling ports for water inflow and outflow, an additional port allowed sampling of a $10-\mathrm{mL}$ air bubble placed in the neck of the 
chamber. The placement of the bubble was designed to minimize contact between water and air yet still allow the fish to access it.

Small adult fish $(2-5 \mathrm{~g} ; N=7)$ were allowed to settle for at least $1 \mathrm{~h}$ as the respirometers were flushed with water of $\mathrm{PO}_{2}$ greater than 120 Torr at $31^{\circ}-32^{\circ} \mathrm{C}$ from the head tank (as described above). This produced a mean water $\mathrm{PO}_{2}$ of about 110 Torr in the respirometers. $\dot{\mathrm{M}}_{2}$ was measured in duplicate, and then the inflowing $\mathrm{PO}_{2}$ was lowered to 50 Torr, which produced a mean water $\mathrm{PO}_{2}$ of about 40 Torr in the respirometers. A $10-\mathrm{mL}$ air bubble was introduced into the neck of the chamber. After a 1-h adjustment period, $\dot{\mathrm{M}}_{2}$ from air was measured by monitoring the depletion of $\mathrm{O}_{2}$ from the air bubble over the next hour, and $\dot{M O}_{2}$ from water was measured by flow-through respirometry twice during the period. Appropriate blank chambers were run to correct for the very slight transfer of $\mathrm{O}_{2}$ from the air phase to the water phase. Measurements of both air and water $\mathrm{PO}_{2}$ 's were made with the Radiometer $\mathrm{O}_{2}$ electrode, as described above.

\section{Blood $\mathrm{O}_{2}$ Dissociation Curves}

A blood pool of $5.5 \mathrm{~mL}$ was obtained from 16 larger adult fish (10-40 g). Fish were first anesthetized in the anesthetic Transmore as described by Wood et al. (1994), and blood was drawn from the hemal arch into syringes prerinsed with 1,000 i.u. $\mathrm{mL}^{-1}$ sodium heparin (Richter) in $180 \mathrm{mmol} \mathrm{L}^{-1}$ $\mathrm{NaCl}$. The blood was diluted about $15 \%$ by this heparinization. The blood was then divided into two $2.75-\mathrm{mL}$ pools and equilibrated with either air or $\mathrm{N}_{2}$ in a homemade tonometry setup consisting of two $10-\mathrm{mL}$ volumetric flasks suspended in a water bath at $30^{\circ}-32^{\circ} \mathrm{C}$ and mounted on a shaker table. Tonometry gas was bubbled first through $180 \mathrm{mmol} \mathrm{L}^{-1} \mathrm{NaCl}$ at the experimental temperature so as to match vapor pressure with that of the blood. A preliminary experiment demonstrated that there was no loss or gain of volume over $4 \mathrm{~h}$ of equilibration. Blood $\mathrm{O}_{2}$ dissociation curves were constructed through the mixing technique of Scheid and Meyer (1978). Various aliquots of oxygenated and deoxygenated blood were mixed in a modified gastight $250-\mu \mathrm{L}$ Hamilton syringe by using a small bead of mercury; 10 mixtures in total were prepared in this way. The $\mathrm{PO}_{2}$ of each mixture was measured with a Radiometer $\mathrm{E} 5046 \mathrm{O}_{2}$ electrode thermostated to the experimental temperature, and the percentage saturation was calculated. The procedure was then repeated after adding $6 \mu \mathrm{mol} \mathrm{HCl}$ (in $3 \mu \mathrm{L}$ of $180 \mathrm{mmol}$ $\mathrm{L}^{-1} \mathrm{NaCl}$ ) per milliliter of whole blood to each tonometer flask, so as to assess the extent of the Bohr effect.

In both control and acidified runs, extracellular $\mathrm{pH}$ and red blood cell intracellular $\mathrm{pH}$ (freeze-thaw method of Zeidler and Kim [1977]) were determined on the $0 \%, 50 \%$, and $100 \%$ saturation mixtures, and hematocrit 
was determined gravimetrically after spinning at 13,000 $\mathrm{g}$ for $2 \mathrm{~min}$. The plasma from the hematocrit determinations was decanted and used to measure plasma total $\mathrm{CO}_{2}$ concentrations by the method of Cameron (1971), and plasma protein concentration by refractometry (Alexander and Ingram 1980). Radiometer $\mathrm{pH}$ (E5021) and $\mathrm{CO}_{2}$ electrodes (E5036) were used for these determinations and displayed on the same Radiometer pHM 71 meter as the $\mathrm{O}_{2}$ electrode.

\section{Results}

\section{Diurnal Temperature and $\mathrm{PO}_{2}$}

The $\mathrm{PO}_{2}$ levels varied in approximate synchrony with temperature at all 14 sites in Fish Springs Lagoon (Fig. 1). Very probably, this was a result of net photosynthetic production of $\mathrm{O}_{2}$ during the day and consumption at night by cyanobacteria. The $\mathrm{pH}$ of this extremely well buffered water did not significantly vary spatially or temporally; mean $\mathrm{pH}$ for all 14 sites was 9.84 (range $=9.76-9.97$ ). Oreochromis alcalicus grabami were present at all 14 sites, sometimes in such quantity that the water appeared dark in areas where the fish congregated in large masses. In Table 1 we present the absolute range of surface data for temperature and $\mathrm{PO}_{2}$ at each site, although we did obtain even lower values for $\mathrm{PO}_{2}$ in a few bottom samples. In general, there was little variation with depth, as the water was well mixed by the high inflow from the springs and by frequent high winds combined with the shallow depth of the lagoon $(<1 \mathrm{~m})$. Temperatures in 12 of 14 sites fluctuated diurnally, ranging from a low of $22^{\circ} \mathrm{C}$ recorded just before dawn to a high of $38^{\circ} \mathrm{C}$ recorded in midafternoon. The temperature in the two other sites (small warm springs feeding the main lagoon) remained fairly constant $\left(35^{\circ}-37^{\circ} \mathrm{C}\right)$, but $\mathrm{PO}_{2}$ did fluctuate diurnally at these sites from $0.30 \mathrm{mg} \mathrm{L}^{-1}$ ( 7.2 Torr) during the night to 3.16 $\mathrm{mg} \mathrm{L}^{-1}$ (77.1 Torr) at midmorning. Figure 2 shows surface temperature and $\mathrm{PO}_{2}$ data for one site (no. 11) where fish were particularly abundant and that is representative of all 12 sites in which temperature fluctuated over a 24-h period. $\mathrm{PO}_{2}$ fluctuated diurnally with temperature at this site; the lowest $\mathrm{PO}_{2}$ was 18.9 Torr at $25^{\circ} \mathrm{C}$ at midnight, and the highest $\mathrm{PO}_{2}$ was 402.4 Torr at $35.5^{\circ} \mathrm{C}$ in midafternoon.

\section{Behavioral Observations}

Many different fish behaviors observed in both the field and the lab appeared to be related to respiration. Fish congregated in dense numbers in the more oxygenated water just below the dam overflow (sites 2 and 
3; Fig. 1) during both day and night, even though piscivorous birds used this site for feeding during daylight hours. Other areas in and adjacent to the lagoon (e.g., pump house pond sites 11-14) were supersaturated (hyperoxic) during the day and almost anoxic at night (Table 1, Fig. 2) but still contained abundant fish. In general, fish were most numerous in thie shallow, warmest areas during the hottest part of the day and retreated to deeper areas at night.

We collected fish by seining in the early morning (0700-0800) when temperatures were lower than those recorded at any diurnal peak (Fig. 2 ). While surface breathing was seen only occasionally before seining, many fish that had escaped the seine were observed breathing at the surface for up to $30 \mathrm{~min}$ after seining. At times, the mouths protruded above the water surface and the fish seemed to be gulping. This did not appear to be a feeding behavior. Oreochromis alcalicus grabami were normally observed grazing on periphytic cyanobacteria; we are not aware of filter feeding in these fish. It is interesting that fish in the pump house pond (sites 11-14) were observed during the day repeatedly jumping

TABLE 1

Range of values for $\mathrm{PO}_{2}$ and temperature at 14 sites in the Fish Springs Lagoon area of Lake Magadi, Kenya in January 1992

\begin{tabular}{|c|c|c|}
\hline Site & $\begin{array}{l}\mathrm{PO}_{2} \text { Range } \\
\text { (Torr) }\end{array}$ & $\begin{array}{l}\text { Temperature Range } \\
\left({ }^{\circ} \mathrm{C}\right)\end{array}$ \\
\hline$\ldots \ldots \ldots$ & $67.7-242.9$ & $31.0-36.5$ \\
\hline$\ldots \ldots \ldots$ & $58.8-192.5$ & $31.0-37.0$ \\
\hline$\ldots \ldots \ldots$ & $91.5-175.6$ & $30.0-36.0$ \\
\hline $4 \ldots \ldots \ldots$ & $51.5-144.6$ & $25.0-36.0$ \\
\hline $5 \ldots \ldots \ldots$ & $15.1-130.8$ & $25.0-36.0$ \\
\hline 6 & $8.3-127.5$ & $24.0-36.0$ \\
\hline$\ldots \ldots \ldots \ldots$ & $26.5-76.5$ & $34.5-37.0$ \\
\hline$\ldots \ldots \ldots \ldots$ & $62.6-223.5$ & $31.0-38.0$ \\
\hline 9 & $59.5-202.5$ & $31.0-37.0$ \\
\hline $10 \ldots \ldots \ldots$ & $7.2-77.1$ & $35.0-37.0$ \\
\hline $11 \ldots \ldots \ldots$ & $18.9-402.4$ & $23.0-38.0$ \\
\hline$\ldots \ldots \ldots \ldots$ & $31.1-220.6$ & $28.0-35.0$ \\
\hline 13 & $19.8-390.5$ & $24.0-38.0$ \\
\hline 14 & $12.7-378.5$ & $23.0-35.0$ \\
\hline
\end{tabular}




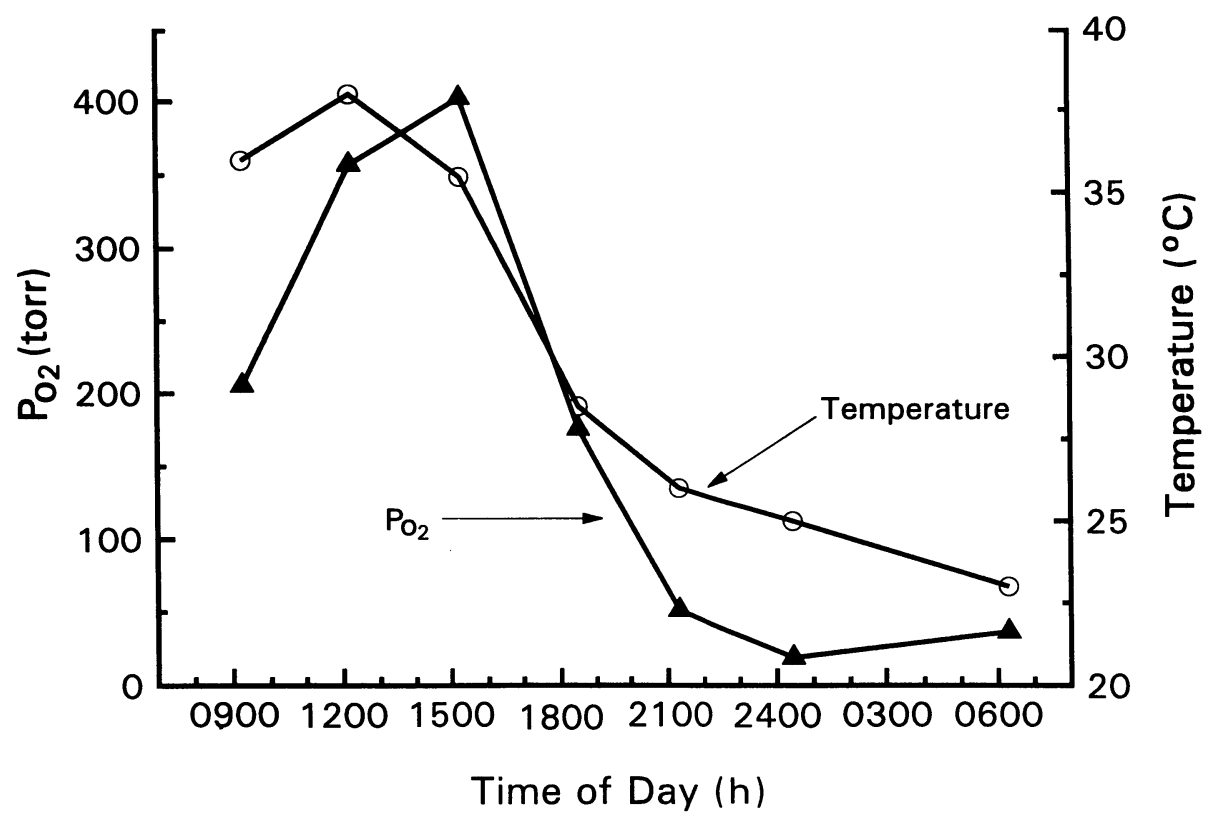

Fig. 2. Fluctuations in water temperature and $\mathrm{PO}_{2}$ (depth $=5-10 \mathrm{~cm}$ below surface) over a 24-b cycle January 29-30, 1992, at site 11 (see Fig. 1), a region with an abundant fish population, at Fish Springs Lagoon area on the edge of Lake Magadi, Kenya.

entirely out of the water to bite off pieces of cyanobacteria growing in mats down the side of the damp stone retaining wall that separated the higher water level in the Fish Springs Lagoon from that in the pump house pond (see Fig. 1). A graze line on the cyanobacterial mat could be seen above the water level.

In the lab, we observed fish gulping at the surface in the 20-L holding buckets when densities were too high or aeration inadequate. This behavior became more common in the late afternoon as water warmed up over the day in the outdoor laboratory. The glass aquarium allowed closer observation of the surface breathing events. While at times the fish appeared to be skimming the better oxygenated surface water, we clearly observed many events where the entire mouth was out of the water and in which air bubbles were later released from the mouth and operculi underwater. We conclude that these fish are not just surface skimming but are actually breathing air as well (though perhaps mixed with water). When males in breeding coloration were placed in the aquarium, they were extremely territorial and spent much of their time in high-energy activities such as chasing, charging, and locking mouths. Under normoxic 
conditions, these behaviors were not followed by surface breathing. However, territorial behavior ceased when hypoxic conditions forced fish to surface breathe.

\section{Temperature Effects on $\dot{\mathrm{M}}_{2}$}

$\dot{\mathrm{MO}}_{2}$ was extremely sensitive to temperature over the naturally occurring range. In a single batch of fish observed during the day as ambient temperature increased, routine $\mathrm{M}_{2}$ under normoxic conditions increased progressively from about $6.6 \mu \mathrm{mol} \mathrm{g} \mathrm{g}^{-1} \mathrm{~h}^{-1}$ at $27^{\circ} \mathrm{C}$ to about $34.5 \mu \mathrm{mol} \mathrm{g} \mathrm{g}^{-1} \mathrm{~h}^{-1}$ at $36^{\circ} \mathrm{C}$ (Fig. 3). Above $36^{\circ} \mathrm{C}, \dot{M}_{2}$ leveled off abruptly; temperature had no significant effect between $36^{\circ}$ and $41^{\circ} \mathrm{C}$. We were able to measure routine $\dot{\mathrm{MO}_{2}}$ at a mean temperature of $41.2^{\circ} \pm 0.3^{\circ} \mathrm{C}$, but at $42.5^{\circ} \mathrm{C}$, fish begin dying. The effective $Q_{10}$ for the temperature range of $27^{\circ}-36^{\circ} \mathrm{C}$ was 6.2 , a very high value.

\section{Temperature Effects on Threshold $\mathrm{PO}_{2}$ for Surface Breathing}

Temperature also had a pronounced effect on the $\mathrm{PO}_{2}$ threshold for surface breathing, which increased significantly from $29.6 \pm 1.9(N=12)$ Torr at $31^{\circ} \mathrm{C}$ to $54.7 \pm 9.5(N=11)$ Torr at $37.5^{\circ} \mathrm{C}$.

\section{Critical $\mathrm{PO}_{2}$ for Survival}

In the closed-system respirometry experiments (no access to air) at $30^{\circ}-$ $33^{\circ} \mathrm{C}$, seven fish died when $\mathrm{PO}_{2}$ was allowed to drop below the required $\mathrm{O}_{2}$ level for survival. The mean $\mathrm{PO}_{2}$ measured at the time of death was 12.6 \pm 0.9 (range $=8.0-15.5$ ) Torr. The three lowest $\mathrm{PO}_{2}$ 's recorded that did not cause death were $16.5,17.5$, and 17.5 Torr, so the threshold was well defined at about 16 Torr.

\section{Effect of Water $\mathrm{PO}_{2}$ on $\dot{M O O}_{2}$}

$\dot{\mathrm{M}}_{2}$, measured at $31^{\circ}-32^{\circ} \mathrm{C}$ by flow-through respirometry, increased slightly as the $\mathrm{PO}_{2}$ of the water was initially decreased from fully saturated down to about 110 Torr, but metabolic rate did not change significantly between 140 and 60 Torr (Fig. 4). $\dot{\mathrm{MO}}_{2}$ then rapidly declined as $\mathrm{PO}_{2}$ was decreased in stages below this level. At a $\mathrm{PO}_{2}$ of less than 50 Torr, some fish began to show signs of respiratory stress, and five of the 12 fish died at a mean $\mathrm{PO}_{2}$ of 31.6 \pm 4.6 (range $=20-47.5$ ) Torr, while the other seven remained alive at a $\mathrm{PO}_{2}$ of about 25 Torr, the lowest level tested. These results indicate a somewhat higher critical $\mathrm{PO}_{2}$ for survival than in the closed-system respi- 


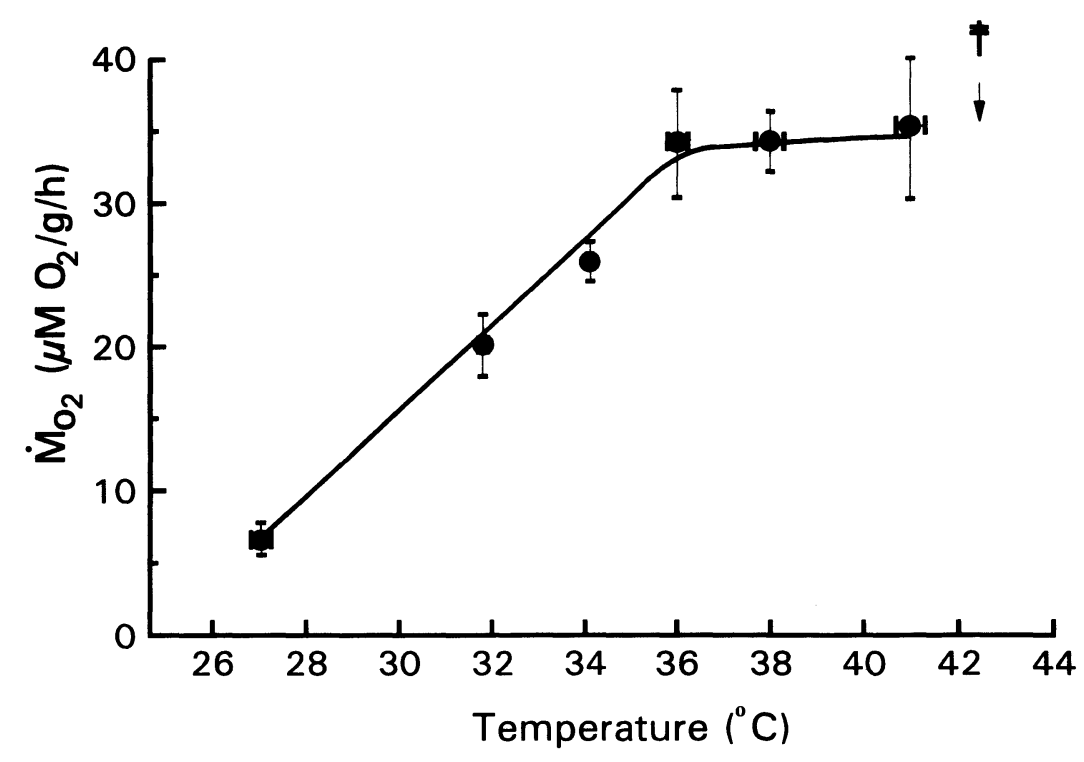

Fig. 3. The influence of environmental temperature on $\dot{\mathrm{MO}}_{2}$ in individual Oreochromis alcalicus grahami, as measured by closed-system respirometry. The same batch of fish $(\mathrm{N}=11)$ was followed at progressively bigher temperatures as ambient temperature increased over the day in the outdoor laboratory. Error bars show means \pm 1 SEM for both $\dot{M}_{2}$ and temperature. Arrow indicates that fish started to die at $42.5^{\circ} \mathrm{C}$. The outcome of ANOVA followed by Duncan's multiple range test on temperature values of $\sim 27^{\circ} \mathrm{C}, \sim 32^{\circ} \mathrm{C}, \sim 34.5^{\circ} \mathrm{C}, \sim 36^{\circ} \mathrm{C},-38^{\circ} \mathrm{C}$, and $\sim 41.5^{\circ} \mathrm{C}$ indicated that the following values are not significantly different from one another at $\mathrm{P}=0.05$ : the $\sim 32^{\circ} \mathrm{C}$ and the $\sim 34.5^{\circ} \mathrm{C}$ values; the $\sim 34.5^{\circ} \mathrm{C}$ and the $\sim 36^{\circ} \mathrm{C}$ values; the $\sim 36^{\circ} \mathrm{C}$, the $\sim 38^{\circ} \mathrm{C}$, and the $\sim 41.5^{\circ} \mathrm{C}$ values; and the $\sim 34.5^{\circ} \mathrm{C}$ and the $\sim 41.5^{\circ} \mathrm{C}$ values.

rometry experiment, but the protocol was different, involving exposure to progressive hypoxia over 5-7 h rather than in $1 \mathrm{~h}$ or less.

\section{$\mathrm{PO}_{2}$ from Water and Air during Hypoxic Conditions}

When mean water $\mathrm{PO}_{2}$ was reduced from about 110 Torr to about 40 Torr at $31^{\circ}-32^{\circ} \mathrm{C}$ in the flow-through respirometry system, five of the seven fish tested used the air bubble for surface breathing. Total $\dot{M O}_{2}$ fell significantly by about a third relative to the normoxic values; of the remaining $\dot{\mathrm{MO}}_{2}, 12.5 \%$ was taken from air and $87.5 \%$ from water (Fig. 5). 


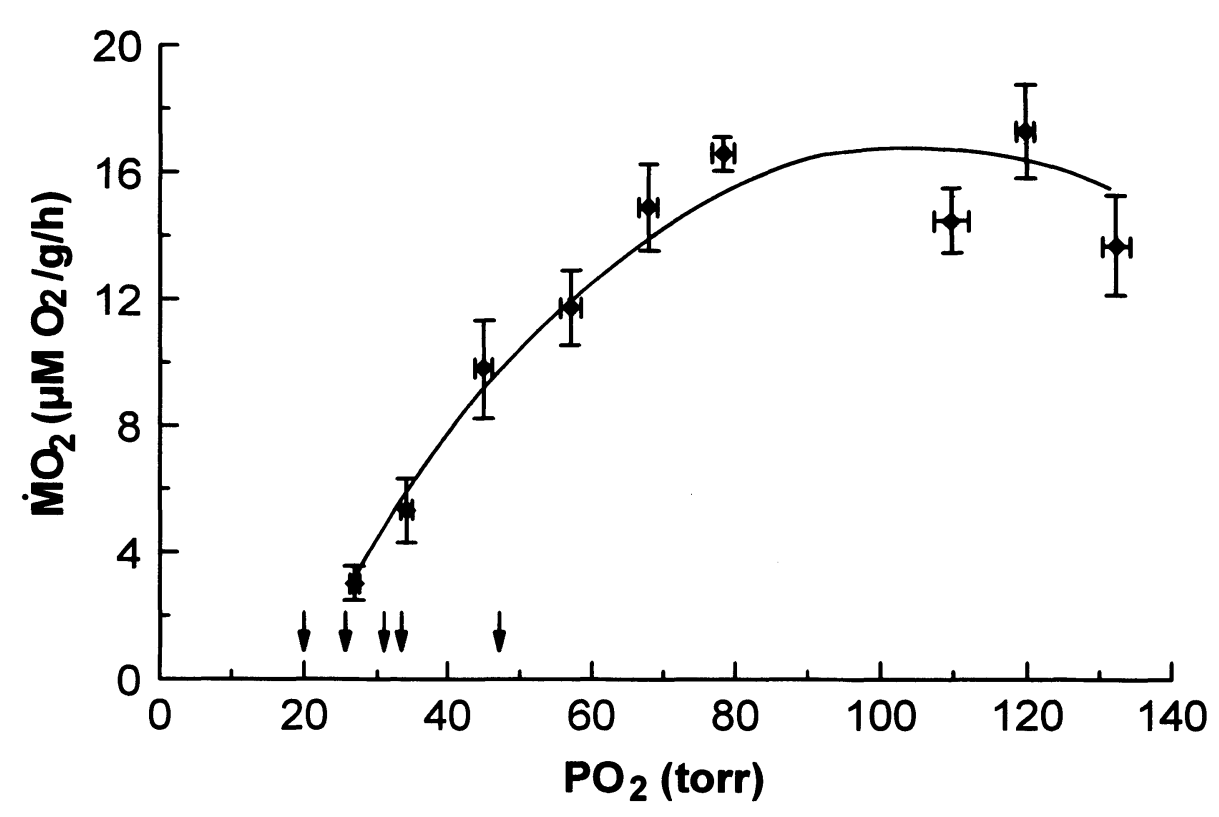

Fig. 4. The influence of environmental $\mathrm{PO}_{2}$ on $\dot{\mathrm{MO}}_{2}$ at $31^{\circ}-32^{\circ} \mathrm{C}$ in individual Oreochromis alcalicus grahami as measured by flow-through respirometry. $\mathrm{PO}_{2}$ was taken as the mean of the inflow and outflow values of the respirometer. The same batch of fish $(N=12)$ was exposed at approximately hourly intervals to seven or eight progressively lower levels of $\mathrm{PO}_{2}$ between about 135 and 25 Torr. Error bars show means \pm 1 SEM for both $\mathrm{MO}_{2}$ and $\mathrm{PO}_{2}$. Arrows indicate $\mathrm{PO}_{2}$ levels at which individual fish died. The outcome of ANOVA followed by Duncan's multiple range test on $\dot{M O}_{2}$ values of $\sim 3.0, \sim 5.3, \sim 9.8, \sim 11.7, \sim 13.7$, 14.4, 14.8, 16.5, and $\sim 17.3$ indicated that the following values are not significantly different from one another at $\mathrm{P}=0.05:$ the $\sim 3.0$ and $\sim 5.3$ values; the $\sim 9.8$ and $\sim 11.7$ values; the $\sim 11.7, \sim 13.7, \sim 14.4$, and $\sim 14.8$ values; and the $\sim 13.7, \sim 14.4, \sim 14.8, \sim 16.5$, and $\sim 17.3$ values.

\section{Blood $\mathrm{O}_{2}$ Dissociation Curves}

The blood $\mathrm{O}_{2}$ dissociation curve of $\mathrm{O}$. alcalicus grabami at $30^{\circ}-32^{\circ} \mathrm{C}$ was hyperbolic, with very low cooperativity (Hill coefficient $=1.18)$ and a high $\mathrm{O}_{2}$ affinity $\left(\mathrm{P}_{50}=6\right.$ Torr at mean extracellular $\mathrm{pH}$ 8.58) (Fig. 6). When the mean extracellular $\mathrm{pH}$ was experimentally lowered to 8.19 with $\mathrm{HCl}$, there was no Bohr shift: $\mathrm{P}_{50}$ remained at 6 Torr. There was no detectable red cell swelling associated with acidification or oxygenation and deoxygenation; hematocrit averaged $18.4 \%$ and plasma protein $2.25 \mathrm{~g}(100 \mathrm{~mL})^{-1}$. There was also no detectable effect of oxygenation and deoxygenation on plasma 


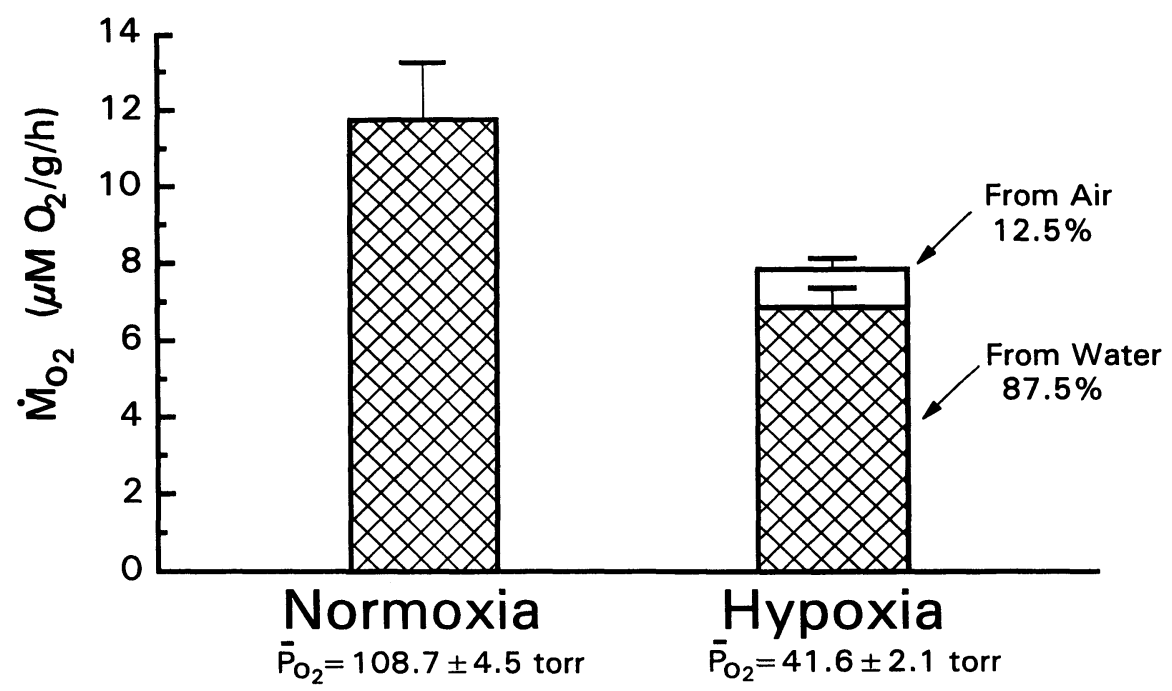

Fig. 5. The partitioning of routine $\dot{M}_{2}$ at $31^{\circ}-32^{\circ} \mathrm{C}$ from air and water in Oreochromis alcalicus grahami under normoxic and bypoxic conditions (mean $\mathrm{PO}_{2}$ levels shown). See text for experimental details. At both $\mathrm{PO}_{2}$ 's, means \pm 1 SEM are reported for the five fish (of seven tested) that exhibited surface breathing at the lower $\mathrm{PO}_{2}$.

$\mathrm{CCO}_{2}$ in either control $\left(\right.$ mean $\left.=8.20 \mathrm{mmol} \mathrm{L}^{-1}\right)$ or acidified runs $(1.91 \mathrm{mmol}$ $\mathrm{L}^{-1}$ ). In contrast, the $\mathrm{pH}$ measurements (Table 2 ) indicated the presence of a Haldane effect, with deoxygenation causing increases in red blood cell intracellular $\mathrm{pH}$ of 0.2 to 0.4 units; effects on extracellular $\mathrm{pH}$ were not clear-cut.

\section{Discussion}

To our knowledge, no other fish is able to live in this particular combination of very high $\mathrm{pH}$, very high alkalinity, and extreme diurnal fluctuations in DO and temperature. The present results cast some light on the respiratory adaptations that allow Oreochromis alcalicus grabami to thrive in this hostile environment. These include (1) a high sensitivity of routine metabolism to temperature over part of the range and insensitivity over another part, which is matched to the natural diurnal temperature and $\mathrm{O}_{2}$ regime; (2) an ability to regulate routine $\mathrm{MO}_{2}$ over a fairly wide range of environmental $\mathrm{PO}_{2}$; (3) short-term tolerance of extremely low environmental $\mathrm{PO}_{2}$; (4) supplementary air and water surface breathing at times of low $\mathrm{O}_{2}$ availability and/or 


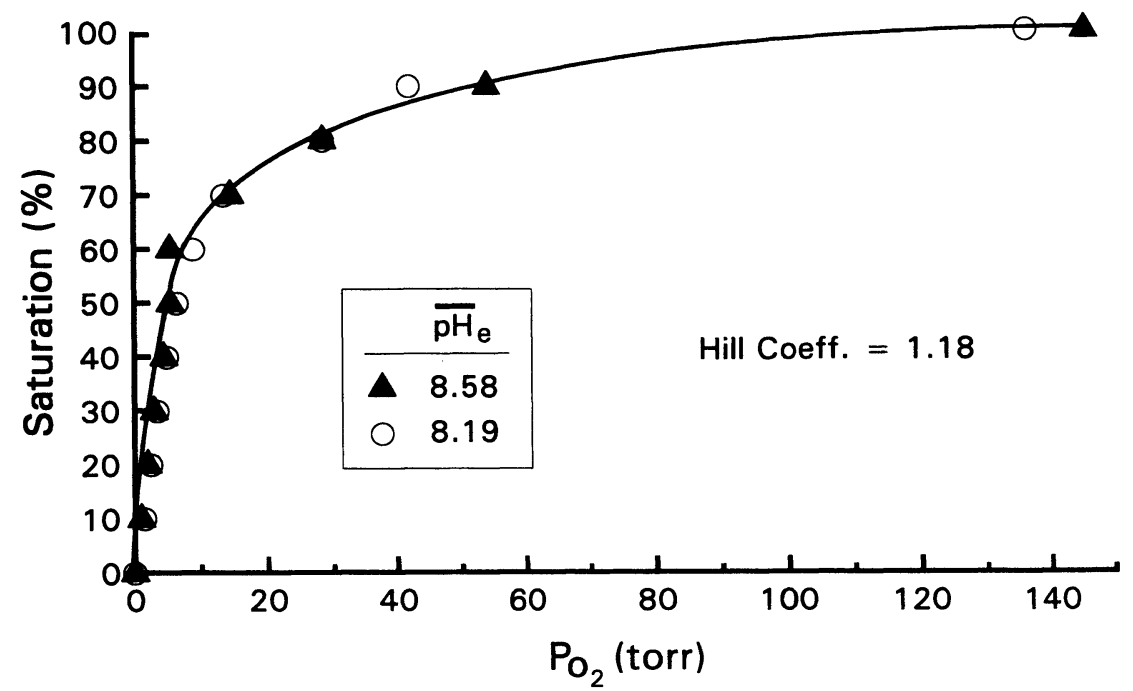

Fig. 6. The oxygen dissociation curve of the blood of Oreochromis alcalicus grahami (pooled from 16 fish) at $30^{\circ}-32^{\circ} \mathrm{C}$, equilibrated with air. There was no detectable Bobr shift ( $P_{50}$ remained at 6 Torr) or other alteration in the curve when the blood was acidified from a mean extracellular pH (pHe) of 8.58 (triangles) to 8.19 (circles) with $\mathrm{HCl}$.

high $\mathrm{O}_{2}$ demand; and (5) a blood $\mathrm{O}_{2}$ dissociation curve with high $\mathrm{O}_{2}$ affinity and low pH sensitivity.

Routine $\dot{\mathrm{M}}_{2}$ and the Effects of Temperature and $\mathrm{PO}_{2}$ in Relation to the Natural Regime

Routine $\dot{M}_{2}$ has been studied extensively in other species of Oreochromis (e.g., O. nilotica(us): Farmer and Beamish [1969]; Magid and Babiker [1975]; Verheyen et al. [1985]; Fernandes and Rantin [1989]; O. mossambica(us): Job [1969a, 1969b]; Kutty [1972]; Caulton [1978]; O. mossambicus $\times$ bornorum: Febry and Lutz [1987]; O. rendelli: Caulton [1977]) and very recently in $O$. alcalicus grabami by Franklin et al. (1995), who examined the size dependence of routine metabolism at $37^{\circ} \mathrm{C}$. The results of the present study are rather different from those on other tilapia in several respects but in relatively good agreement with those of Franklin et al. (1995) on O. alcalicus grabami. For example, we recorded a routine $\dot{\mathrm{MO}}_{2}$ of about $34.5 \mu \mathrm{mol} \mathrm{g}$ $\mathrm{h}^{-1}$ for 2 -g fish at $36^{\circ}-38^{\circ} \mathrm{C}$ (Fig. 3), while their reported allometric equation yields a routine $\dot{\mathrm{MO}}_{2}$ (after a longer settling period) of about $28 \mu \mathrm{mol} \mathrm{g}$ $\mathrm{h}^{-1}$ for 2 -g fish at $37^{\circ} \mathrm{C}$. Upon acutely raising temperature from $37^{\circ}$ to $42^{\circ} \mathrm{C}$, they recorded a small increase (30\%) in $\dot{M}_{2}$, whereas we found no signif- 
TABLE 2

The influence of oxygenation status on plasma $\mathrm{pH}$ ( $\mathrm{pHe}$ ) and red blood cell intracellular $\mathrm{pH}$ ( $\mathrm{pHi}$ ) in the blood of Oreochromis alcalicus grabami at $30^{\circ}-32^{\circ} \mathrm{C}$

\begin{tabular}{llll}
\hline$\% \mathrm{O}_{2}$ Saturation & $0 \%$ & $50 \%$ & $100 \%$ \\
\hline $\begin{array}{l}\text { Control: } \\
\text { pHe } \ldots \ldots \ldots \ldots \ldots\end{array}$ & 8.56 & 8.60 & \\
pHi $\ldots \ldots \ldots \ldots \ldots$ & 7.91 & 7.96 & 7.69 \\
Acidified. & & & \\
pHe $\ldots \ldots \ldots \ldots \ldots$ & 8.23 & 8.26 & 8.08 \\
pHi $\ldots \ldots \ldots \ldots$ & 7.78 & 7.63 & 7.41 \\
\hline
\end{tabular}

Note. Duplicate measurement was taken for $\mathrm{pHe}$ and single measurements were taken for pHi on a common blood pool from 16 fish.

icant change when temperature was gradually increased over this range (Fig. 3). Both studies indicate that routine $\dot{\mathrm{M}}_{2}$ in the Magadi tilapia at the normal peak daytime temperature in the Fish Springs Lagoon area (about $38^{\circ} \mathrm{C}$; Table 1 , Fig. 2 ) is extremely high and relatively temperature insensitive.

To our knowledge, these routine metabolic rates are the highest reported in poikilothermic teleosts. This is perhaps not surprising in view of the high activity level of Magadi tilapia (we almost never observed stationary fish under normoxia, either in the wild or in the respirometers) and the high environmental temperature that would be lethal to most teleosts. Several other tilapia do tolerate this high temperature range but exhibit 25\%-60\% lower $\dot{\mathrm{M}}_{2}$ 's at comparable temperatures above $35^{\circ} \mathrm{C}$ ( Job $1969 a, 1969 b$; Caulton 1977, 1978; Fernandes and Rantin 1989). A more striking difference from other tilapia is the transition from temperature insensitivity of $\dot{M O}_{2}$ above $36^{\circ} \mathrm{C}$ to marked sensitivity below this temperature (Fig. 3). The $\mathrm{Q}_{10}$ from $27^{\circ} \mathrm{C}$ to $36^{\circ} \mathrm{C}$ was 6.2 , in comparison to $1.0-3.0$ over the same range in other tilapia. This may be suitable to the natural diurnal cycle of dissolved $\mathrm{O}_{2}$ and temperature in the Fish Springs Lagoon area. Thus, at night, when $\mathrm{O}_{2}$ availability in water is lowest (Fig. 2) due to cyanobacterial respiration, metabolic $\mathrm{O}_{2}$ demand is only a fraction of that during the day because of the simultaneous decline of water temperature to the $23^{\circ}-28^{\circ} \mathrm{C}$ range (Fig. 3). Birds at Lake Magadi do not feed at night, so the need for energy expenditure for predator avoidance at this time is likely reduced. In contrast, 
during the heat of the day, the fish can sustain a high metabolic rate for feeding, social, and predator escape behaviors, and this rate is more or less independent of exact environmental temperature right up to the lethal limit ( $\sim 42.5^{\circ} \mathrm{C}$; Fig. 3). This upper lethal temperature is almost identical to that reported in other studies on O. alcalicus grabami (Coe 1966; Reite et al. 1974; Johnston et al. 1994).

In their study on Blennius pholis, Bridges et al. (1984) found a diurnal fluctuation in $\mathrm{PO}_{2}$ in intertidal rock pool sites similar to the diurnal fluctuation in our study (Fig. 2) but with two noticeable differences-no corresponding fluctuation in temperature and a pH fluctuation similar in magnitude to $\mathrm{Po}_{2}$. In comparable studies on pupfish from saline waters in the southwest United States, Stuenkel and Hillyard (1981) found that the metabolic rates of fish acclimated to freshwater and half-strength seawater increased with increased acclimation temperatures. However, the plasma osmolality of fish acclimated to seawater decreased significantly, and the fish were able to osmoregulate efficiently at higher temperatures $\left(25^{\circ}-30^{\circ} \mathrm{C}\right)$.

At the intermediate temperature where $\dot{\mathrm{M}}_{2}$ was measured $\left(31^{\circ}-32^{\circ} \mathrm{C}\right)$, O. alcalicus grabami proved to be a good $\mathrm{O}_{2}$ regulator, maintaining $\dot{\mathrm{M}}_{2}$ until a $\mathrm{PO}_{2}$ of about 60 Torr (Fig. 4). Exact quantitative comparisons with other species are difficult because of methodological considerations, as pointed out by Fernandes and Rantin (1989). For example, some authors incorrectly plot $\mathrm{MO}_{2}$ against inflowing $\mathrm{PO}_{2}$ rather than against directly determined inspired or averaged $\mathrm{PO}_{2}$, and techniques for defining the inflection point vary. Nevertheless, tilapia in general appear to be good $\mathrm{O}_{2}$ regulators, with $\mathrm{PO}_{2}$ dependence starting in the $\mathrm{PO}_{2}$ range of 30-90 Torr (Dusart 1963; Job 1969b; Kutty 1972; Magid and Babiker 1975; Verheyen et al. 1985; Fernandes and Rantin 1989). The Magadi tilapia is therefore similar to other tilapia species in this respect.

We observed movement of the fish into the shallowest, warmest water where food supply and $\mathrm{O}_{2}$ availability (due to cyanobacterial growth and photosynthesis) were greatest during the day, and a retreat to deeper, cooler water and/or sites of aeration such as the dam outflow at night. This pattern was originally noted in the Magadi tilapia by Coe (1966) and has been reported in other tilapia as well (Caulton 1982). Thus a combination of metabolic and behavioral characteristics match this fish to the severe natural regime.

Short-Term Tolerance of Severe Hypoxia and the Importance of Surface Breathing

When the above-mentioned metabolic and behavioral adaptations prove insufficient, there appear to be two more that the animal can recruit. The 
first fallback mechanism, which is essentially metabolic, is an ability to resist extremely low $\mathrm{PO}_{2}$ for short periods. The second, essentially behavioral, is an ability to breathe at the water surface.

The survival threshold at $30^{\circ}-33^{\circ} \mathrm{C}$ for short-term hypoxic exposure (i.e., $<1 \mathrm{~h}$ ) was well-defined at about $16 \mathrm{Torr}$, and somewhat higher ( $\sim 32$ Torr) when hypoxia was imposed in progressive steps over 5-7 h. In the lagoon, we observed fish living in conditions as severe as approximately 7 Torr $(0.3$ $\mathrm{mg} \mathrm{L}^{-1}$ at $36^{\circ} \mathrm{C}$ ), although it is likely that they did not spend long periods in such hypoxic areas. This tolerance appears to be characteristic of tilapia in general; comparable figures for short-term tolerance are approximately 10 Torr at $23^{\circ} \mathrm{C}$ in Oreochromis shirana chilwae (Morgan 1972), approximately 5 Torr at $24^{\circ} \mathrm{C}$ in Oreochromis macrochir (Dusart 1963), and almost 0 Torr at $25^{\circ} \mathrm{C}$ in Oreochromis niloticus (Verheyen et al. 1985). This characteristic may result from an ability to suppress metabolic rate and/or a capacity for anaerobic metabolism, both of which may prove fruitful areas for future research on the Magadi tilapia.

Surface breathing (aquatic surface respiration; reviewed by Kramer and McLure [1982]; Gee and Gee [1995]) is a common adaptation to aquatic hypoxia in tropical fish. The benefits of this strategy in improving arterial oxygenation under hypoxic conditions have been shown by Burggren (1982). In some species, the behavior involves only the extraction of $\mathrm{O}_{2}$ from the upper several millimeters of water, which are better oxygenated, while in others additional benefits are achieved by mixing water with air in the mouth, by holding air bubbles next to a well-vascularized buccal epithelium, and even by taking air into the swim bladder. Based on our observations, both in the field and in the aquarium, and on our anatomical studies of the swim bladder and buccal epithelium (Maina et al. 1996; J. N. Maina, unpublished data), we suspect that $O$. acalicus grabami exploits all of these behaviors. Both the buccal epithelium and the physostomous swim bladder are very well vascularized; the latter has surface infoldings and can be inflated by the fish when held in air, and blood draining from the swim bladder joins with the branchial arches (Maina et al. 1996). Tilapia are not usually considered to be air or surface breathers, but we have found two anecdotal reports of apparent surface-breathing behavior in other tilapia species subjected to acute hypoxia (Dusart 1963; Morgan 1972). Our observations on fish chased by seining in the lagoon suggest that surface breathing may also be used to help pay off excess postexercise $\mathrm{O}_{2}$ consumption (formerly " $\mathrm{O}_{2}$ debt").

Experiments at $31^{\circ}-32^{\circ} \mathrm{C}$ demonstrated that under moderate hypoxia, surface-breathing fish obtained a small but significant fraction (12.5\%) of their $\dot{\mathrm{M}}_{2}$ from the air phase, although this was not sufficient to sustain routine $\dot{\mathrm{M}}_{2}$ at normoxic levels (Fig. 5). We predicted that this fraction 
would become more important at a higher temperature, but our intention to repeat the experiment at $37.5^{\circ} \mathrm{C}$ was thwarted by logistic problems. Instead, we conducted the simple experiment of measuring the $\mathrm{PO}_{2}$ threshold at $31^{\circ} \mathrm{C}$ versus $37.5^{\circ} \mathrm{C}$. The threshold was significantly higher (1.8-fold) at the higher temperature, in accord with these ideas.

\section{Blood $\mathrm{O}_{2}$ Transport Characteristics}

The $\mathrm{O}_{2}$ dissociation characteristics of $\mathrm{O}$. alcalicus grabami (determined at $\left.30^{\circ}-32^{\circ} \mathrm{C}\right)$ exhibit an extremely high $\mathrm{O}_{2}$ affinity $\left(\mathrm{P}_{50}=6\right.$ Torr $)$, low cooperativity (Hill coefficient $=1.18$ ), and an insensitivity to $\mathrm{pH}$ in the tested range (8.2-8.6; Fig. 6). It must be noted that these curves were determined only at a $\mathrm{PCO}_{2}$ close to 0 Torr (i.e., with air/ $\mathrm{N}_{2}$ equilibration only), again a logistic consequence of research in an isolated location. However, inasmuch as this fish lives in a " $\mathrm{PCO}_{2}$ vacuum" caused by an external $\mathrm{pH}$ close to 10 (Johansen et al. 1975; Wood et al. 1989), it is likely that arterial $\mathrm{PCO}_{2}$ is extremely low in vivo anyway. On the basis of reviewing studies of other teleosts at high environmental $\mathrm{pH}$, we have argued elsewhere (Wood et al. 1994) that true resting arterial extracellular $\mathrm{pH}$ in vivo may be as high as 8.7, and true arterial $\mathrm{PCO}_{2}$ is well below 1 Torr. Therefore, the conditions of the equilibrations appear realistic, and the $\mathrm{pH}$ range tested probably represents the normal variation between rest (8.6) and exercise (8.2).

The present results agree with those of the only previous study on the blood of this species, by Lykkeboe et al. (1975). These workers reported a $\mathrm{P}_{50}$ of 4 Torr, a Hill coefficient of 1.2, and the absence of a Bohr effect (and Root effect) over the $\mathrm{pH}$ range $7.5-8.5$ at $35^{\circ} \mathrm{C}$. However, what is remarkable is that Lykkeboe et al. (1975) determined these properties using a dialysed hemolysate (stripped hemoglobin), whereas we found almost identical values using intact whole blood. Assuming that the two studies can be compared, this suggests that the intracellular milieu (red blood cell intracellular $\mathrm{pH}$, ions, organic phosphates) has negligible effect on $\mathrm{O}_{2}$ transport in the Magadi tilapia, a conclusion that is supported by the intracellular and extracellular pH insensitivity (Fig. 6, Table 2 ). In most other species, the intracellular milieu alters the binding properties of the hemoglobin such that whole blood behaves differently from stripped hemoglobin (Perry and McDonald 1993). For example, in O. niloticus at $30^{\circ} \mathrm{C}$, Verheyen et al. (1985) determined that whole blood exhibited a $\mathrm{P}_{50}$ of 23 Torr, a Hill coefficient of 1.54 , and a large Bohr effect, while stripped hemoglobin exhibited a $\mathrm{P}_{50}$ of 3 Torr, a Hill coefficient of 1.20, and a small Bohr effect. Bridges et al. (1984) found a Bohr shift in the hemoglobin of $B$. pholis, which, like $O$. alcalicus grabami, lives in an environment with an exaggerated diurnal fluctuation in $\mathrm{PO}_{2}$. However, unlike the $\mathrm{pH}$ in Lake Magadi thermal pools, the $\mathrm{pH}$ in the intertidal rock pools fluctuates from 7.6 to 9.6 within a 24 -h period. 
The absence of a Bohr effect in the Magadi tilapia is not due to a failure of extracellular $\mathrm{pH}$ changes to alter red blood cell intracellular $\mathrm{pH}$. The measurements of Table 2 indicate a fairly standard relationship between extracellular and intracellular $\mathrm{pH}$, explicable by normal Donnan distribution, such that the extracellular $\left[\mathrm{H}^{+}\right] /$intracellular $\left[\mathrm{H}^{+}\right]$rises as extracellular $\mathrm{pH}$ falls; that is, changes in red blood cell intracellular $\mathrm{pH}$ reflect, but are smaller than, changes in extracellular $\mathrm{pH}$. Surprisingly, these measurements also suggest that there is a definite Haldane effect manifested as a 0.2-0.4-unit decrease in red blood cell intracellular $\mathrm{pH}$ with oxygenation, despite the lack of Bohr effect. The Haldane effect is generally considered the reciprocal of the Bohr effect: oxygenation releases Bohr protons from the hemoglobin molecule so that oxygenated blood exhibits a lower $\mathrm{pH}$ and $\mathrm{CCO}_{2}$ (Jensen 1989). In the present study, the effect was seen clearly only in red blood cell intracellular $\mathrm{pH}$ and not in extracellular $\mathrm{pH}$ or plasma $\mathrm{CO}_{2}$ measurements. Unfortunately, erythrocytic $\mathrm{CCO}_{2}$ was not measured in these experiments. In the absence of more data, speculation on mechanisms is unwarranted, but the possible uncoupling of the Haldane effect from the Bohr effect in this species deserves further investigation.

In conclusion, our blood $\mathrm{O}_{2}$ results reinforce the arguments of Lykkeboe et al. (1975) that the high $\mathrm{O}_{2}$ affinity and $\mathrm{pH}$ insensitivity of blood $\mathrm{O}_{2}$ binding are present for an extremely active fish with a high metabolic rate living in a frequently hypoxic environment. $\mathrm{O}_{2}$ uptake will be maximized regardless of exercise-induced $\mathrm{pH}$ changes or environmental $\mathrm{PO}_{2}$ fluctuations over a wide range. In combination with the unusually high respiratory surface area and low diffusion distance of the gills (Maina 1990), the unusual temperature sensitivity of metabolic $\mathrm{O}_{2}$ demand, numerous behavioral adaptations, and the ability to withstand acute hypoxia and perform supplementary surface and/or air breathing, these blood characteristics allow O. alcalicus grabami to thrive in one of the most hostile aquatic environments on earth.

\section{Acknowledgments}

This research was supported by grants from the North Atlantic Treaty Organization, Natural Sciences and Engineering Council (NSERC) of Canada International Collaborative Program, and U.S. National Geographic Society to the team, and from the NSERC Research Program to C.M.W., U.S. National Science Foundation Program (IBN-9118819) to P.J.W., Centre National de la Recherche Scientifique of France to P.L., and the University of Wyoming to H.L.B. We thank the Office of the President, Republic of Kenya, for permission to conduct this research, the management and staff of Magadi Soda Company and Mr. George Muthee for tremendous logistic support, and 
DHL Nairobi, who came through for us, unlike the competition. We thank Drs. C. Franklin and I. Johnston for access to unpublished data. And, we thank the PZ referees for their helpful comments.

\section{Literature Cited}

Al.FXANIDER J.B. and G.A. Ingram. 1980. A comparison of five of the methods commonly used to measure protein concentrations in fish sera. J. Fish Biol. 16:115-122.

Boutilifr R.G., T.A. Heming, and G.K. Iwama. 1984. Physiochemical parameters for use in fish respiratory physiology. Pp. 403-430 in W.S. HOar and D.J. Ranidal.L, eds. Fish Physiology. Vol. 10. Academic Press, New York.

Bridges C.R., A.C. TAYlor, S.J. Morris, and M.K. Grieshaber. 1984. Ecophysiological adaptations in Blennius pholis blood to intertidal rockpool environments. J. Exp. Mar. Biol. Ecol. 77:151-167.

BuRGGREN W.W. 1982. "Air gulping" improves blood oxygen transport during aquatic hypoxia in the goldfish Carassius auratus. Physiol. Zool. 55:327-334.

Cameron J.N. 1971. Rapid method for determination of total carbon dioxide in small blood samples. J. Appl. Physiol. 31:632-634.

- 1984. Acid-base status of fish at different temperatures. Am. J. Physiol. 246: R452-R459.

CAUliton M.S. 1977. The effect of temperature on routine metabolism in Tilapia rendalli (Boulenger). J. Fish Biol. 11:549-553.

- 1978. The effect of temperature and mass on routine metabolism in Sarotherodon (Tilapia) mossambicus (Peters). J. Fish Biol. 13:195-201.

1982. Feeding, metabolism and growth of tilapias: some quantitative considerations. Pp. 157-180 in R.S.V. Pullin and R.H. Lowe-McConnell, eds. The Biology and Culture of Tilapias. International Center for Living Aquatic Resources Management, Manila.

Cof M.J. 1966. The biology of Tilapia grabami (Boulenger) in Lake Magadi, Kenya. Acta Trop. 23:146-176.

Dusar'T J. 1963. Contribution a l'étude de l'adaptation des tilapia (Pisces Cichlidae) a la vie en milieu mal oxygène. Hydrobiologia 21:328-341.

EDISY F.B., O.S. BAMFORD, and G.M.O. MaloIy. 1981. $\mathrm{Na}^{+}$and $\mathrm{Cl}^{-}$effluxes and ionic regulation in Tilapia grahami, a fish living in conditions of extreme alkalinity. J. Exp. Biol. 91:349-353.

EDisy F.B. and G.M.O. Malory. 1984. Ionic content of body fluids and sodium efflux Oreochromis alcalicus grahami, a fish living at temperatures above $30^{\circ} \mathrm{C}$ and in conditions of extreme alkalinity. Comp. Biochem. Physiol. 78A:359-361.

Farmer G.J. and F.W.H. Beamish. 1969. Oxygen consumption of Tilapia nilotica in relation to swimming speed and salinity. J. Fisheries Res. Board Can. 26:28072821.

FEBRY R. and P. LuTz. 1987. Energy partitioning in fish: the activity-related cost of osmoregulation in a euryhaline cichlid. J. Exp. Biol. 128:63-85.

FERNANIDES M.N. and F.T. RANTIN. 1989. Respiratory responses of Oreochromis niloticus (Pisces, Cichlidae) to environmental hypoxia under different thermal conditions. J. Fish Biol. 25:509-519. 
Franki.in C.E., T. Crockford, I.A. Johnston, and C. Kamunde. 1994. The thermostability of haemoglobins from the hot-spring fish, Oreochromis alcalicus grabami: comparisons with Antarctic and temperate species. J. Therm. Biol. 19:277-280.

FRANKL.IN C.E., I.A. JohnSTON, T. CROCKFORD, and C. KAMUNDE. 1995. Scaling of oxygen consumption in Lake Magadi tilapia, Oreochromis alcalicus grabami: a fish living at $37^{\circ} \mathrm{C}$. J. Fish Biol. 46:829-834.

FRY F.E.J. 1957. The aquatic respiration of fish. Pp. 1-63 in M.E. Brown, ed. The Physiology of Fishes. Vol. 1. Academic Press, New York.

GeE J.H. and P.A. GeE. 1995. Aquatic surface respiration, buoyancy control and the evolution of air-breathing in gobies (Gobiidae: Pisces). J. Exp. Biol. 198:79-89.

JENSEN F.B. 1989. Hydrogen ion equilibria in fish haemoglobins. J. Exp. Biology 143: 225-234.

Jов S.V. $1969 a$. The respiratory metabolism of Tilapia mossambica (Teleostei). I. The effect of size, temperature, and salinity. Mar. Biol. 2:121-126.

- 1969b. The respiratory metabolism of Tilapia mossambica (Teleostei). II. The effect of size, temperature, salinity, and partial pressure of oxygen. Mar. Biol. 3:222-226.

Johansen K., G.M.O. Maloiy, and G. Lykkeboe. 1975. A fish in extreme alkalinity. Respir. Physiol. 24:159-162.

Johnston I.A., F.B. EdDY, and G.M.O. MaLoIy. 1983. The effects of temperature on muscle $\mathrm{pH}$, adenylate and phosphagen concentrations in Oreochromis alcalicus grahami, a fish adapted to an alkaline hotspring. J. Fish Biol. 23:717-724.

Johnston I.A., H. Guderly, C.E. Franklin, T. Crockford, and C. Kamunde. 1994. Are mitochondria subject to evolutionary temperature adaptation? J. Exp. Biol. 195:293-306.

KRAMER D.L. and M. MCCluRe. 1982. Aquatic surface respiration, a widespread adaption to hypoxia in tropical freshwater fishes. Environ. Biol. Fishes 7:47-55.

KuTTY M.N. 1972. Respiratory quotient and ammonia excretion in Tilapia mossambica. Mar. Biol. 16:126-133.

Laurent P., H.L. Bergman, A. Narahara, P.J. Wal.sh, J.N. Maina, and C.M. Wood. 1995. Gill structure of a fish from an alkaline lake: effect of exposure to $\mathrm{pH}$ 7. Can. J. Zool. 73:1170-1181.

Leatherl.ANd J.F., M. Hyder, and D.M. Ensor. 1974. Regulation of plasma $\mathrm{Na}^{+}$and $\mathrm{K}^{+}$concentrations in five African species of Tilapia fishes. Comp. Biochem. Physiol. 48A:699-710.

LyKkeisoe G., K. Johansen, and G.M.O. Maloiy. 1975. Functional properties of hemoglobins in the teleost Tilapia grahami. J. Comp. Physiol. 104:1-11.

MAETZ J. and G. De Renzis. 1978. Aspects of the adaptation of fish to high external alkalinity; comparison of Tilapia grahami and T. mossambica. Pp. 213-228 in K. Schmidt-Nielsen, L. Bolis, and S.H.P. Maddrell, eds. Comparative Physiology: Water, Ions and Fluid Mechanics. Cambridge University Press, Cambridge.

MAGID A.M.A. and M.M. BABIKER. 1975. Oxygen consumption and respiratory behavior of three Nile fishes. Hydrobiologia 46:359-367.

MAINA J.N. 1990. A study of the morphology of the gills of an extreme alkalinity and hyperosmotic adapted teleost Oreochromis alcalicus grabami (Boulenger) with particular emphasis on the ultrastructure of the chloride cells and their modifications with water dilution: a SEM and TEM study. Anat. Embryol. 181:83-98.

Maina J.N., C.M. Wood, A.B. Narahara, H.L. Bergman, P. Lalirent, and P.J. Walsh. 1996. Morphology of the swim bladder of a cichlid teleost: Oreochromis alcalicus 
grahami (Trewavas, 1983), a fish adapted to a hyperosmotic, alkaline and hypoxic environment: a brief outline of the structure and function of the swim bladder. In J.S. Munshi and H.M. DutTA, eds. Horizons of New Research in Fish Morphology in the 20th Century. Oxford and IBH, New Delhi (in press).

Maloiy G.M.O., G. LyKKeboe, K. Johansen, and O.S. BAMfORd. 1978. Osmoregulation in Tilapia grahami: a fish in extreme alkalinity. Pp. 229-238 in K. SCHMIDT-Niel.sen, L. Bol.Is, and S.H.P. MADDRELL, eds. Comparative Physiology: Water, Ions and Fluid Mechanics. Cambridge University Press, Cambridge.

Morgan P.R. 1972. Causes of mortality in the endemic tilapia of Lake Chilwa (Malawi). Hydrobiologia 40:101-119.

Perry S.F. and D.G. McDonald. 1993. Gas exchange. Pp. 251-278 in D.H. Evans, ed. The Physiology of Fishes. CRC, Boca Raton, Fla.

Randall D.J., C.M. Wood, S.F. Perry, H.L. Bergman, G.M.O. Maloiy, T.P. Mommsen, and P.A. WRIGHT. 1989. Urea excretion as a strategy for survival in a fish living in a very alkaline environment. Nature 337:165-166.

Reite, O.B., G.M.O. Maloiy, and B. Aasehaug. 1974. pH, salinity and temperature tolerance of Lake Magadi tilapia. Nature 247:315.

SCheid P. and M. Meyer. 1978. Mixing technique for study of oxygen-hemoglobin equilibrium: a critical evaluation. J. Appl. Physiol. 45:818-822.

Skadhauge E., C.P. Lechene, and G.M.O. Maloiy. 1980. Tilapia grahami: role of intestine in osmoregulation under conditions of extreme alkalinity. Pp. 133-142 in B. LAHLOU, ed. Epithelial Transport in Lower Vertebrates. Cambridge University Press, Cambridge.

Stuenkel E.L. and S.D. Hillyard. 1981. The effects of temperature and salinity acclimation on metabolic rate and osmoregulation in the pupfish, Cyprinodon salinus. Copeia 2:411-417.

Trewevas E. 1983. Tilapiine Fishes of the Genera Sarotherodon, Oreochromis and Danakilia. British Museum of Natural History, Dorchester.

Verheyen E., R. Blust, and C. Doumen. 1985. The oxygen uptake of Saratherodon niloticus $\mathrm{L}$. and the oxygen binding properties of its blood and hemolysate (Pisces: Cichlidae). Comp. Biochem. Physiol. 81A:423-426.

Walsh P.J., H.L. Bergman, A.B. Narahara, C.M. Wood, P.A. Wright, D.J. Randall, J.N. MAINA, and P. LAURENT. 1993. Effects of ammonia on survival, swimming and activities of enzymes of nitrogen metabolism in the Lake Magadi tilapia (Oreochromis alcalicus grabami). J. Exp. Biol. 180:323-387.

Wood C.M., H.L. Bergman, P. Laurent, J.N. Maina, A. Narahara, and P.J. Walsh. 1994. Urea production, acid-base regulation, and their interactions in the Lake Magadi tilapia, a unique teleost adapted to a highly alkaline environment. J. Exp. Biol. 189:13-36.

Woon, C.M., S.F. Perry, P.A. Wright, H.L. Bergman, and D.J. Ranidal.. 1989. Ammonia and urea dynamics in the Lake Magadi tilapia, a teleost fish adapted to an extremely alkaline environment. Respir. Physiol. 77:1-20.

Wright P.A., S.F. Perry, D.J. Randall, C.M. Wood, and H.L. Bergman. 1990. The effects of reducing water $\mathrm{pH}$ and total $\mathrm{CO}_{2}$ on a teleost fish adapted to an extremely alkaline environment. J. Exp. Biol. 151:361-369.

Zeidier R. and D.H. Kim. 1977. Preferential hemolysis of postnatal calf red cells induced by internal alkalinization. J. Gen. Physiol. 70:385-401. 